\title{
Development of an Advanced Robotics Program For Middle and High School VEX Robotics Students
}

\author{
Ryan B. Tang Dan, Mechatronics Engineering, Maharshi Patel, Mechatronics Engineering \\ Vaughn College of Aeronautics and Technology, United States, bobby.tang@vaughn.edu, maharshi.patel@vaughn.edu
}

\begin{abstract}
The paper outlines a project idea of creating an advanced STEM program that improves the competition outcomes of first-year middle and high school students in the VEX Robotics Competition. The program consists of three semesters based on the New York State competition season, engineering design process, and individual team progress. The STEM program also includes simplified college-level courses such as engineering math and physics, kinematics, dynamics, as well as advanced courses such as control systems and PID tuning. The program also provides students with the knowledge and tools in engineering and professional skills that better prepare them for a career in a STEMrelated field. These professional skills include technical presentations, public speaking, interview, teamwork, leadership, and communication.
\end{abstract}

Keywords-STEM, Robotics, Engineering, Design Process, VEX Robotics, CAD Design

\section{INTRODUCTION}

\section{A. VEX Robotics Competition}

The VEX Robotics International Competition, presented by the Robotics Engineering and Competition (REC) Foundation, provides an annual engineering challenge in STEM education for middle and high school students throughout the world. The competition works to promote STEM to students and learning communities internationally and aiding with the development of such skills like teamwork, leadership, communication, and presentation.

The competition is played on a 12 by 12 -foot field with two alliance colors, red and blue. Each alliance is composed of two teams that form a red and blue alliance. The objective of the game is to obtain a higher score than the opposing alliance at the end of the two-minute match. A competition match consists of a 15 second autonomous period followed by a oneminute 45 -second driver control period. In the autonomous period, the teams must use their programming skills to produce an autonomous robot path that would be able to score as many points as possible. After an autonomous winner has been decided and the referees have added an autonomous bonus score, the driver control period of the match begins. In the driver mode, teams must collaborate to obtain a higher score in the 1-minute 45-second timeframe. [1]

Each year, the competition features a unique STEM challenge played with different scoring objects and methods. In the 2019-2020 VEX Tower Takeover Challenge, there are sixty-six cubes and seven Towers placed around the field. The field contains 22 green, 22 orange, and 22 purple cubes. There

Digital Object Identifier (DOI):

http://dx.doi.org/10.18687/LACCEI2020.1.1.669

ISBN: 978-958-52071-4-1 ISSN: 2414-6390 are five neutral towers as well as two alliance specific Towers that may only be utilized by robots of the same alliance. The cubes can be placed in the Towers or scored in goal zones. The cubes are worth one point when placed in a goal zone. The exact value of each cube is determined by how many cubes of that specific color have been placed in towers. Each cube of the same color placed in the tower adds one additional point to each cube in the goal zone. In the autonomous period, the winning alliance is awarded a sixpoint autonomous bonus and awarded two purple cubes that can be introduced at any time during the driver control period.

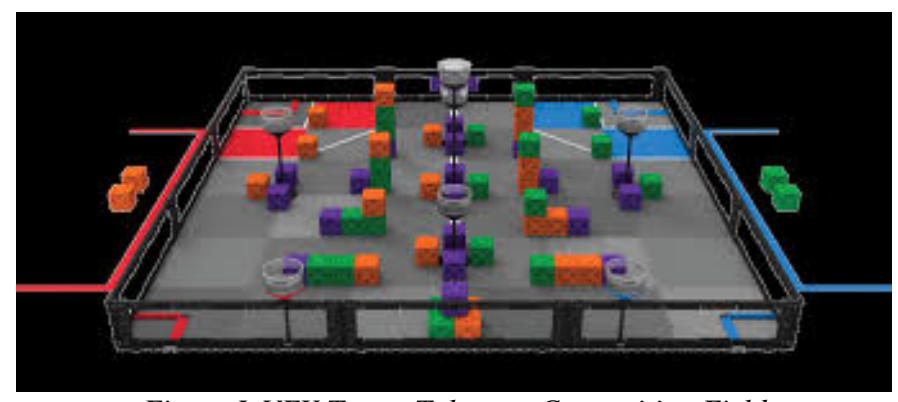

Figure I. VEX Tower Takeover Competition Field

\section{B. The Skills Challenge}

In addition to the main competition, there is a Robot Skills Challenge section. The Robot Skills challenge requires teams to compete individually in a 1-minute period where they must attempt to score as many points as possible. The field is set up in the same layout as a competition matches, but with slight differences in the rules. The robot skills challenge is comprised of two individual scores that are then combined to obtain the final score. The first score is the programming score in which students must create an autonomous that will score as many points as possible in one minute. The second score is the driver score obtained through a driver control period of one minute in which a driver controls the robot and scores as much as possible. In the robot skills challenge for the Tower Takeover season, there are no alliances, allowing the team access to all four goal zones and towers. Also, the color of the cubes on the field isn't taken into consideration during scoring.

In any given tournament, each team is allowed three attempts in programming and driver control. The highest score for each category is then combined to create one final total score. This final score determines the team's world, national, and state ranking for the competition season. The robot skills challenge is entirely optional, and teams can choose not to participate. However, participation in the skills challenge 
increases the teams' chances to qualify for the State Championship.

\section{The Competition Season}

The competition season consists of several tiers, and teams must win at each tier to participate in the final tournament, the VEX World Championship. These tiers consist of regionals, states, and world championship. The regional tournaments are the first step into getting an invitation to the World Championship. Figure II below shows the competition season path.

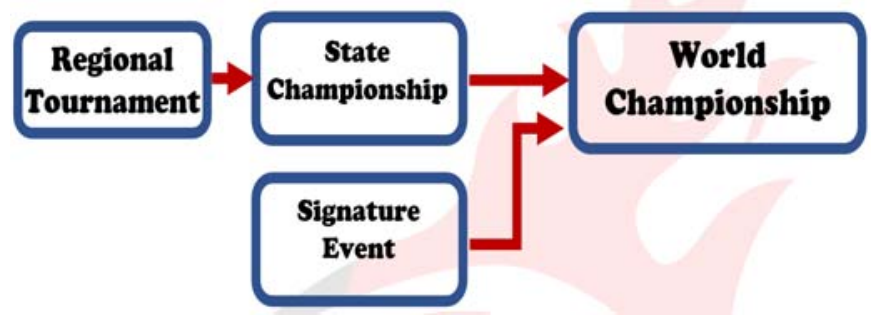

Figure II. VEX Robotics Competition Season Path

These tournaments are most of the competition season, and the only requirement to attend these tournaments is to be an official VEX registered team. In these tournaments, teams compete with the robots that have built to reach a rank in the top sixteen seeds. These sixteen seeds will then choose a partner team and compete in the final's elimination bracket. Only when a team has won the championship will they get an invitation to the VEX state championship. However, winning the tournament is not the only way to get into the state championship. An invitation can also be received by ranking first in the robot skills challenge or receiving specific judge awards. Due to it being regional tournaments, there are no limits as to how many tournaments a team can participate in; this means any team has unlimited chances until the date of the last regional tournament to earn a qualification seat at the state championship.

The state championship is a once a year event that occurs in February or March. In each state and country, there is only a limited number of qualification seats available for the World Championship event. During this event, students compete with their teams in the main tournament, robot skills challenge, and judging interview to win one of the few qualifying awards. In addition to the State Championship, there are several events categorized as signature events. These events host up to more than one hundred teams from all over the world and mimic the world championship event on a smaller scale. These events are separate from the primary competition season and provide qualification seats for the World Championship. Signature events require no prerequisite qualifications and are open to any $\mathrm{VEX}$ registered team.
The World Championship event is the biggest in the competition season and hosts the best teams of the season from all over the world. The middle school division consists of more than 200 300 teams competing at the event. The high school team consists of more than 700 teams competing at the event. These teams split into several sub-divisions that compete until a champion has been crowned. Then the subdivisions create a new elimination bracket that will compete for the World Champion title.

D. The Judge Awards

The final section of the VEX Robotics Competition is the judge awards. The judge awards are awarded to teams by a panel of judges who consider a set of key criteria. These include the engineering notebook, design, competition rankings, robot skills challenge rankings, robotics program quality, team conduct, and professionalism. The judging process consists of the submission of the engineering notebook by VEX teams in the morning, followed by an interview with the judges. In the interview, students discuss their design process, autonomous programming, competition strategy, and all other aspects of the VEX competition. Once the interview is complete, the panel of judges observe the teams in the competition and consider team rankings in the skills challenge and main tournament.

After deliberations, the judges nominate and award specific judge awards to teams based on the awards' criteria. Specific judge awards, such as the Excellence and Design awards, also qualify students for the next higher competition in the season.

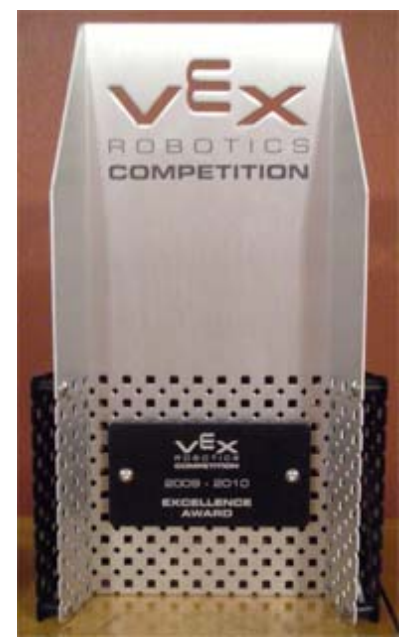

Figure III. VEX Robotics Competition Excellence Award

\section{E. The Overclock Robotics Team}

The 16099/16699 Overclock Robotics Team is a team based in Flushing, New York. The team was founded in 2016 and has competed every year since in the VEX Robotics Competition. In total, the organization consists of three high school teams and two middle school teams. The Overclock robotics team was used to implement the robotics program in 
training completely new students each year into an efficient robotics team. Students from the Vaughn College robotics team (VCAT) were chosen to create this mentorship, implementing a more robust and efficient robotics STEM program.

\section{THE STEM PROGRAM}

A problem that many middle and high school teams encounter is the development of a strong STEM program that will provide students with the tools necessary to succeed. As a result, many students and teams are not able to perform as well as lose interest in pursuing STEM education. A training program was developed that incorporated all aspects of STEM education with the addition of university-level engineering courses and principles. The STEM program was separated into three distinct semesters. The three semesters were set to follow the VEX Competition season, engineering design process, as well as the individual teams' progress.

\section{A. The Introductory Semester}

The initial program consists of an after-school program that introduces students to technology and basic engineering principles. This includes 3D Design, Computer-Aided Design, mathematics, as well as physics with the inclusion of kinematics and dynamics. Education researchers have shown that early introduction to engineering concepts and design prepares and interests students for a career in engineering. The purpose of this section of the program is to introduce engineering principles and critical thinking. As the students develop critical thinking skills, they will be better prepared for the VEX competition robots for the upcoming year. [3]

Table I. Introductory Semester Syllabus

\begin{tabular}{||c|l||}
\hline Class & \multicolumn{1}{|c|}{ Topic } \\
\hline $\mathbf{0}$ & Orientation and Introduction to the STEM Program. \\
\hline $\mathbf{1}$ & Introduction to 3D design and spatial visualization. \\
\hline $\mathbf{2}$ & Introduction to Solidworks Computer Aided Design. \\
\hline $\mathbf{3}$ & Intermediate Solidworks CAD Design. \\
\hline $\mathbf{4}$ & Intermediate Solidworks CAD Design. \\
\hline $\mathbf{5}$ & 3D printing and manufacturing process. \\
\hline $\mathbf{6}$ & Midterm Examination \\
\hline $\mathbf{7}$ & Hands on soldering and electrical systems. \\
\hline $\mathbf{8}$ & Mathematical formulations for robot design \\
\hline $\mathbf{9}$ & Mathematical formulations for robot design part II. \\
\hline $\mathbf{1 0}$ & Introduction to engineering physics and kinematics \\
\hline $\mathbf{1 1}$ & Engineering kinematics and dynamics \\
\hline $\mathbf{1 2}$ & Final Examination \\
\hline
\end{tabular}

The initial start of the program began with an introduction to the Computer-Aided Design (CAD) software, Solidworks. In introducing spatial visualization and 3D design, students will be able to understand basic design and critical thinking skills in developing solutions to problems. The CAD lectures consisted of an introduction to creating self-designed parts, modification of existing Solidworks components, as well as CAD assembly. After the introduction to CAD design, students are introduced to additive manufacturing and manufacturing design process. This allows them to be able to create complex components that are assembled to create a working prototype. Furthermore, it provides students with an understanding that there exists a solution to every problem they encounter while participating in the VEX robotics competition. The figures below show the results of the Solidworks CAD lectures.

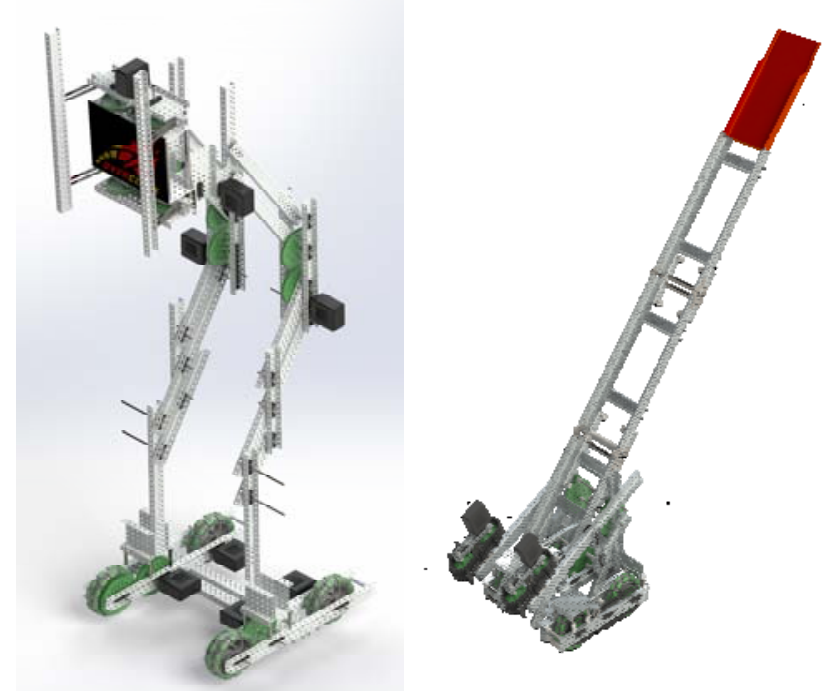

Figure IV. Robot Design CAD Renderings for VEX Competition

In the next lecture, students are given a quick review in middle and high school mathematics. This provides students with a review of basic mathematical concepts to introduce college-level engineering, mathematics, and physics. In providing students with an understanding of basic college mathematics and engineering concepts, students can better understand mechanical design concepts such as torque, speed, friction, and kinematic principles such as momentum, translation, rotation, and combined translation.

\section{B. The Summer Training Semester}

The summer is the most important semester of the training program as students did not need to attend school. Thus, the summer schedule consisted of three-hour lectures on Monday, Wednesday, and Friday. Students were engaged in lectures and discussion of engineering concepts and principles, competitive robot design, and VEX components. This summer program is also designed to prepare students with most of the knowledge necessary to begin their robot designs and competition season.

Furthermore, with the new season competition challenge released, students are also split into teams to develop their robots for the competition season. Students can use the time outside of lecture to experiment with new designs as well as prepare for the competition season. In doing so, it creates a 
professional work environment and provides students with responsibility in remaining active and communicating with their team. In general, the summer training program was separated into mechanical, electrical, programming, and teamwork components of the VEX competition.

Table II. Summer Semester Syllabus

\begin{tabular}{|c|c|c|}
\hline Week & Class & Topic \\
\hline \multirow{3}{*}{1} & 1 & Introduction to the new VEX Competition Challenge \\
\hline & 2 & Drivetrain design, gears, and drivetrain optimization \\
\hline & 3 & Drivetrain analysis and building different drivetrains. \\
\hline \multirow{3}{*}{2} & 4 & Introduction to robot lifts and their advantages \\
\hline & 5 & Building lifts and analysis of lift efficiency. \\
\hline & 6 & Robot lift modifications and combination of lift types. \\
\hline \multirow{3}{*}{3} & 7 & Design of end manipulators and degrees of freedom. \\
\hline & 8 & Design and working with acrylic and plastics. \\
\hline & 9 & Midterm Examination. \\
\hline \multirow{3}{*}{4} & 10 & Introduction to VEX sensors and measurements. \\
\hline & 11 & Introduction to VEXCode programming and logic \\
\hline & 12 & Introduction to function calls with passed parameters. \\
\hline \multirow{3}{*}{5} & 13 & Introduction to the VEX joystick and driver control. \\
\hline & 14 & Introduction to VEX autonomous development. \\
\hline & 15 & VEX path planning and programming practice. \\
\hline \multirow{3}{*}{6} & 16 & Midterm II Examination and Competition Field Setup \\
\hline & 17 & Public speaking and presentation skills workshop. \\
\hline & 18 & Technical writing and Engineering notebook design. \\
\hline \multirow{3}{*}{7} & 19 & Basic Electronics and Electronic components Part II \\
\hline & 20 & Technical Group Presentation Workshop \\
\hline & 21 & VEX interview process and interview skills. \\
\hline \multirow{3}{*}{8} & 22 & Engineering mathematics and physics review \\
\hline & 23 & Advanced engineering mathematics and engineering. \\
\hline & 24 & $\mathrm{AC} / \mathrm{DC}$ Circuits and introduction to basic electronics \\
\hline
\end{tabular}

As seen above in Table 2, the first topic of the summer program is a review of the VEX competition challenge analysis. This provides students with an understanding of the VEX Competition challenge as well as give students an opportunity to discuss designs that would be effective for the challenge with minimal prior exposure to VEX robotics competition. After an introduction to the VEX competition challenge, students are provided with an introduction to the mechanical design of the three key components of a robot. This consists of the drivetrain, expanding lift structure, and the end manipulator. As students learn the concept of each subsystem of the robot, examples of previously used designs in the competition are provided and group discussion is used to analyze their efficiency and effectiveness for this year's challenge. Mathematical formulations and explanations were also provided to give students an understanding of the concepts and principles that were necessary for creating these designs. [2]

After the mechanical segment of the summer program, students were introduced to robot sensors, sensor implementation and calibration. The sensors covered included the ultrasonic, shaft encoder, touch, line tracking, vision, and
Inertial Measurement Unit sensor. Students were also introduced to VEXCode programming basics and how to navigate the VEXCode Text environment. After introducing basic programming concepts, students were then introduced to more advanced programming concepts such as function calls, parameters, Boolean logic. Furthermore, students were introduced to the VEX joystick controller and joystick mapping. Following driver control, students were introduced to path planning, and the development of an efficient and accurate autonomous for competition matches and the robot skills challenge. [4]

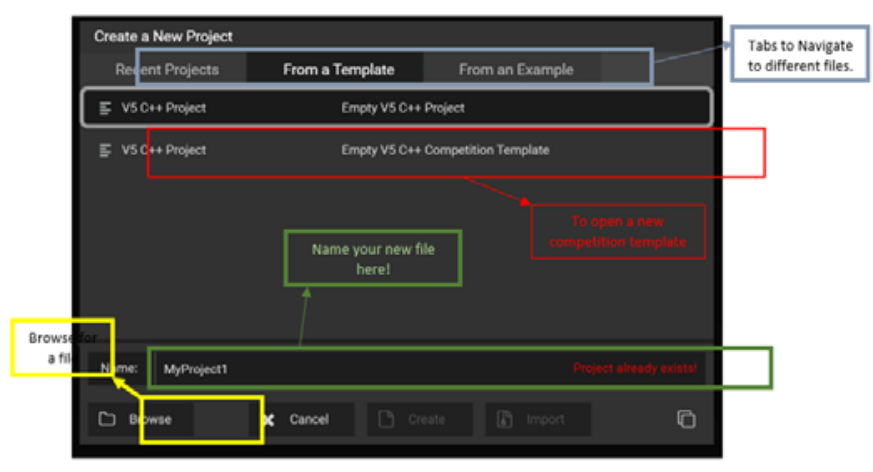

Figure IV. VEXCode Text Sample Lecture Material.

The third segment of the course provides students with workshop and lessons in improving public speaking and technical presentations. Students were provided with an understanding to the different methods of creating a technical presentation to explain their assigned robot designs. In addition, technical writing skills were taught to provide students with the skills to develop an engineering notebook for the judging interview. This provides students with the necessary life skills for future interviews and presentations. [5]

\section{The Competition Semester}

In the competition season, students continued to work with their teams assigning roles to each member of the team. During this semester, students are given zero classes and learning is done through weekly team meetings with the coach. Each team is required to meet with the coaches weekly to discuss new designs, concepts students are struggling with, and introduction of new concepts that may benefit their team's progress. In creating a freedom-based class schedule during the competition season, students have developed the ability to become independent as well as find new methods to solve critical problems, as well as function as a professional engineering team. Furthermore, through peer tutoring, students can develop better work ethics in self research and learning. This providing them with the motivation to continue research and learning independently outside of class.

In total, the competition schedule for the Overclock robotics team consisted of six regional tournaments, two state championships (one middle school and one high school), as 
well as the World Championship. The competition schedule is shown in the table below.

Table III. Overclock Robotics Team Competition Schedule

\begin{tabular}{||c|c||}
\hline Date & Competition Location \\
\hline November 23, 2019 & Jericho High School \\
\hline December 14, 2019 & Roslyn High School \\
\hline January 5, 2020 & Farmingdale High School \\
\hline January 18, 2020 & Adelphi University \\
\hline February 1, 2020 & Freeport High School \\
\hline February 29, 2020 & Vaughn College \\
\hline March 7, 2020 & The Harvey School \\
\hline March 14, 2020 & Harpursville Central High School \\
\hline
\end{tabular}

In the table above, the Overclock robotics team competed in six regional tournaments from November until February. In these tournaments, all five Overclock robotics team participated in the tournament regardless of being middle school or high school. Due to insufficient middle school teams in the New York State division, the middle school and high school division tournaments are not held separately.

\section{The COMPETITION SEASON OUTCOME}

\section{A. The High School Competition Season}

The competition season consisted of several tournament matches that the teams were required to specified awards in order to move on to the next tier event. The figure below shows the overall results of the regional competitions attended by Overclock at different stages of the competition season and training program for the 16099 high school teams. These rankings are the results prior to the elimination rounds.

Table IV. Overclock High School Competition Outcomes

\begin{tabular}{|c|c|c|c|}
\hline Date & Competition & \multicolumn{2}{|c|}{ Rankings } \\
\hline \multirow{3}{*}{ November 23, 2019} & \multirow{3}{*}{ Jericho High School } & 16099A & 11 \\
\hline & & 16099B & 3 \\
\hline & & $16099 \mathrm{C}$ & 16 \\
\hline \multirow{3}{*}{ December 14, 2019} & \multirow{3}{*}{ Roslyn High School } & 16099A & 1 \\
\hline & & 16099B & 4 \\
\hline & & $16099 \mathrm{C}$ & 7 \\
\hline \multirow{3}{*}{ January 5, 2020} & \multirow{3}{*}{ Farmingdale High School } & $16099 \mathrm{~A}$ & 1 \\
\hline & & $16099 \mathrm{~B}$ & 9 \\
\hline & & $16099 \mathrm{C}$ & 2 \\
\hline \multirow{3}{*}{ January 18,2020} & \multirow{3}{*}{ Adelphi University } & $16099 \mathrm{~A}$ & 16 \\
\hline & & 16099B & 1 \\
\hline & & $16099 \mathrm{C}$ & 2 \\
\hline \multirow{3}{*}{ February 1, 2020} & \multirow{3}{*}{ Freeport High School } & 16099A & 4 \\
\hline & & 16099B & 2 \\
\hline & & $16099 \mathrm{C}$ & 5 \\
\hline \multirow{3}{*}{ February 29, 2020} & \multirow{3}{*}{$\begin{array}{l}\text { Vaughn College of } \\
\text { Aeronautics and } \\
\text { Technology }\end{array}$} & 16099A & 37 \\
\hline & & 16099B & 4 \\
\hline & & $16099 \mathrm{C}$ & 41 \\
\hline \multirow{3}{*}{ March 7, 2020} & \multirow{3}{*}{$\begin{array}{l}\text { The Harvey School } \\
\text { State Championship }\end{array}$} & $16099 \mathrm{~A}$ & 17 \\
\hline & & 16099B & 1 \\
\hline & & $16099 \mathrm{C}$ & 18 \\
\hline
\end{tabular}

The season was a successful one in creating well-rounded high school robotics teams. Although the teams' rankings prior to elimination bracket was not the highest, it can be attributed to many different factors. This includes computer generated alliances in qualifier rounds, robot damage from previous matches, and more. However, the high school teams were able to change the outcome in the elimination bracket by choosing each other as alliance partners. In the end the three high school teams were able to remain tournament champion, tournament finalist, or tournament semi-finalists at every tournament. In addition, 16099C received the Amaze Award, Excellence Award and Build Award.

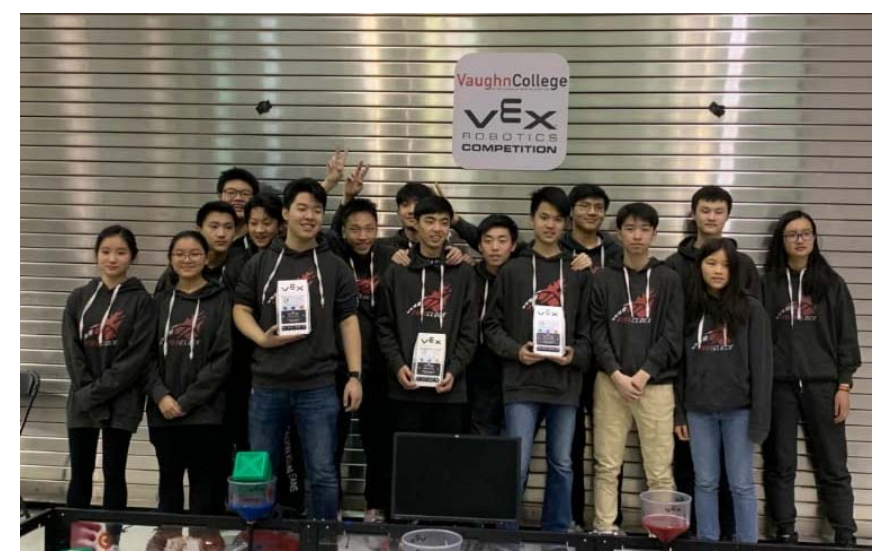

Figure V. 16099A and 16099B Tournament Finalist Award

At the Harvey School Southern New York State Championship, teams 16099A and 16099B were able to win the Southern New York State Championship Tournament Champions award. Thus, qualifying both teams for the World Championship event. Team $16099 \mathrm{C}$ also received a qualification spot for the World Championship through the Robot Skills Challenge.

\section{B. The Middle School Competition Season}

Due to a limited number of middle school teams in the New York State division, middle school VEX teams were required to compete in the high school division at regional tournaments. However, a separate middle school championship was held in New York state for all middle school teams in both the Northern and Southern division of New York. Below are the ranking results for the six regional tournaments in New York State.

Table V. Overclock High School Competition Outcomes 


\begin{tabular}{|c|c|c|c|}
\hline Date & Competition & \multicolumn{2}{|c|}{ Rankings } \\
\hline \multirow[b]{2}{*}{ November 23, 2019} & \multirow[b]{2}{*}{ Jericho High School } & $16699 \mathrm{Y}$ & 13 \\
\hline & & $16699 \mathrm{Z}$ & 20 \\
\hline \multirow[t]{2}{*}{ December 14, 2019} & \multirow[t]{2}{*}{ Roslyn High School } & $16699 \mathrm{Y}$ & 12 \\
\hline & & $16699 \mathrm{Z}$ & 14 \\
\hline \multirow[t]{2}{*}{ January 5, 2012} & \multirow[t]{2}{*}{ Farmingdale High School } & $16699 \mathrm{Y}$ & 10 \\
\hline & & $16699 \mathrm{Z}$ & 17 \\
\hline \multirow[t]{2}{*}{ January 18,2020} & \multirow[t]{2}{*}{ Adelphi University } & $16699 \mathrm{Y}$ & $\overline{14}$ \\
\hline & & $16699 \mathrm{Z}$ & 23 \\
\hline \multirow[t]{2}{*}{ February 1,2020} & \multirow[t]{2}{*}{ Freeport High School } & $16699 \mathrm{Y}$ & $\overline{1}$ \\
\hline & & $16699 \mathrm{Z}$ & 6 \\
\hline \multirow[t]{2}{*}{ February 29, 2020} & \multirow{2}{*}{$\begin{array}{c}\text { Vaughn College of } \\
\text { Aeronautics and Technology }\end{array}$} & $16699 \mathrm{Y}$ & 31 \\
\hline & & $16699 \mathrm{Z}$ & 27 \\
\hline
\end{tabular}

In competing in the high school division, the middle school teams were able to maintain within the top seeds and were chosen for the elimination bracket at five of the six regional tournaments. Team $16699 \mathrm{Z}$ was also able to receive an Excellence award at the Vaughn College of Aeronautics and Technology qualifier. Both teams were able to receive a qualification for the New York State Middle School State Championship. However, due to the COVID-19 Virus, the middle school state championship was cancelled.

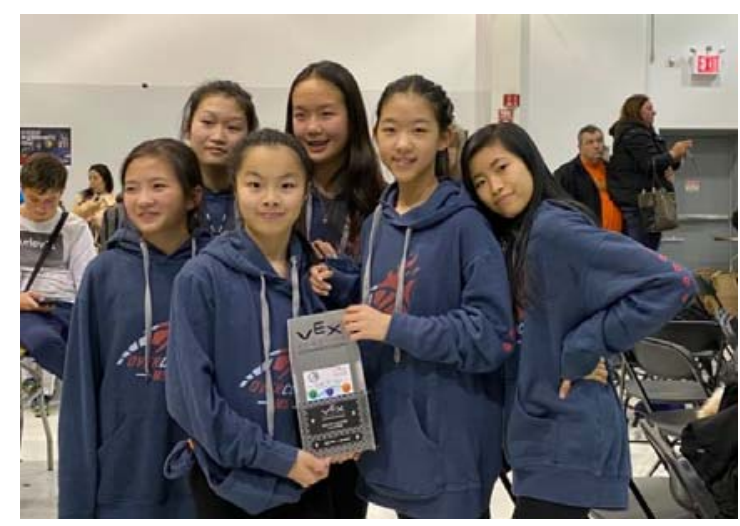

Figure VI. Team 16699Z Excellence Award

\section{B. The Robot Skills Challenge}

The Robot Skills Challenge provided an excellent opportunity for the students to challenge their abilities in VEX robotics. Furthermore, the Skills Challenge provided the students with a second method at qualifying for the next tier event. Similar to the main tournament, the tournament rankings, there exists only one division for both middle and high school teams. The table below shows the outcomes for the 16099 Overclock high school teams.

Table VI. Overclock High School
Robot Skills Challenge Rankings

\begin{tabular}{|c|c|c|c|}
\hline Date & Competition & \multicolumn{2}{|c|}{ Rankings } \\
\hline \multirow{3}{*}{ November 23, 2019} & \multirow{3}{*}{ Jericho High School } & $16099 \mathrm{~A}$ & 1 \\
\hline & & 16099B & 17 \\
\hline & & $16099 \mathrm{C}$ & 5 \\
\hline \multirow{3}{*}{ December 14, 2019} & \multirow{3}{*}{ Roslyn High School } & 16099A & 1 \\
\hline & & 16099B & 8 \\
\hline & & $16099 \mathrm{C}$ & 3 \\
\hline \multirow{3}{*}{ January 5, 2020} & \multirow{3}{*}{$\begin{array}{l}\text { Farmingdale High } \\
\text { School }\end{array}$} & $\overline{16099 \mathrm{~A}}$ & 1 \\
\hline & & 16099B & 2 \\
\hline & & $16099 \mathrm{C}$ & 3 \\
\hline \multirow{3}{*}{ January 18, 2020} & \multirow{3}{*}{ Adelphi University } & $\overline{16099 \mathrm{~A}}$ & 1 \\
\hline & & 16099B & 3 \\
\hline & & $16099 \mathrm{C}$ & 4 \\
\hline \multirow{3}{*}{ February 1, 2020} & \multirow{3}{*}{ Freeport High School } & $16099 \mathrm{~A}$ & 1 \\
\hline & & 16099B & 2 \\
\hline & & $16099 \mathrm{C}$ & 4 \\
\hline \multirow{3}{*}{ February 29, 2020} & \multirow{3}{*}{$\begin{array}{c}\text { Vaughn College of } \\
\text { Aeronautics and } \\
\text { Technology }\end{array}$} & $16099 \mathrm{~A}$ & 1 \\
\hline & & 16099B & 2 \\
\hline & & $16099 \mathrm{C}$ & 43 \\
\hline \multirow{3}{*}{ March 7, 2020} & \multirow{3}{*}{$\begin{array}{l}\text { The Harvey School } \\
\text { State Championship }\end{array}$} & $16099 \mathrm{~A}$ & 3 \\
\hline & & 16099B & 10 \\
\hline & & $16099 \mathrm{C}$ & 4 \\
\hline
\end{tabular}

The Robot Skills Challenge scores above showed that for most of the regionals season, all three high school teams were able to hold the top rankings at most regional events in New York State. Team 16099C was unable to perform robot skills challenge at the Vaughn College Qualifier Tournament due to damage to the robot during tournament match. In the robot skills challenge, 16099A Overclock was able to remain the robot skills challenge champion at rank 1 for all six regional tournaments.

Table VII. Overclock Middle School Robot Skills Challenge Rankings

\begin{tabular}{||c|c|c|c||}
\hline Date & Competition & \multicolumn{2}{|c|}{ Rankings } \\
\hline \multirow{2}{*}{ November 23, 2019 } & \multirow{2}{*}{ Jericho High School } & $16699 \mathrm{Y}$ & 12 \\
\cline { 3 - 4 } & Roslyn High School & $16699 \mathrm{Z}$ & 14 \\
\hline December 14, 2019 & & $16699 \mathrm{Y}$ & 9 \\
\hline January 5, 2012 & Farmingdale High School & $16699 \mathrm{Z}$ & 6 \\
\cline { 3 - 4 } & & $16699 \mathrm{Y}$ & 4 \\
\hline January 18, 2020 & Adelphi University & $16699 \mathrm{Y}$ & 5 \\
\cline { 3 - 4 } & & $16699 \mathrm{Z}$ & 13 \\
\hline February 1, 2020 & Freeport High School & $16699 \mathrm{Y}$ & 3 \\
\hline February 29, 2020 & Vaughn College of & $16699 \mathrm{Z}$ & 5 \\
\hline & Aeronautics and Technology & $166999 \mathrm{Y}$ & 6 \\
\hline
\end{tabular}


In Table VII, we were able to see that the middle school Overclock teams were still able to maintain relatively high rankings in the New York State Tournaments. In the end team 16699Y was able place rank one in the New York State Skills standing and ranked $43^{\text {rd }}$ in the world skills standing. Team $16099 \mathrm{~A}$ at the end of the competition season was able to rank 113 in the high school world standing and third in the New York State division. The table below shows the final awards results of all five Overclock teams.

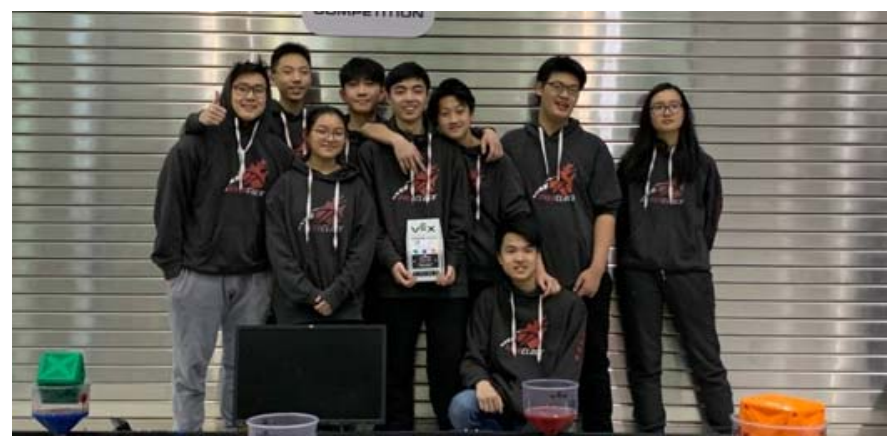

Figure VII. Team 16099A Robot Skills Champion Award

Table VIII. Overclock Competition Season Awards

\begin{tabular}{|c|c|c|c|}
\hline Date & Competition & Award & Team \\
\hline $\begin{array}{c}\text { November 23, } \\
2019 \\
\end{array}$ & $\begin{array}{l}\text { Jericho High } \\
\text { School }\end{array}$ & Robot Skills Champion & $16099 \mathrm{~A}$ \\
\hline \multirow{2}{*}{$\begin{array}{c}\text { December } 14, \\
2019\end{array}$} & \multirow{2}{*}{$\begin{array}{l}\text { Roslyn High } \\
\text { School }\end{array}$} & Excellence Award & $16099 \mathrm{C}$ \\
\hline & & Robot Skills Champion & $16099 \mathrm{~A}$ \\
\hline \multirow{5}{*}{ January 5, 2020} & \multirow{5}{*}{$\begin{array}{l}\text { Farmingdale } \\
\text { High School }\end{array}$} & Tournament Champion & $16099 \mathrm{~A}$ \\
\hline & & Tournament Champion & 16099B \\
\hline & & Robot Skills Champion & $16099 \mathrm{~A}$ \\
\hline & & Build Award & $16099 \mathrm{C}$ \\
\hline & & Create Award & $16699 \mathrm{Z}$ \\
\hline \multirow[b]{3}{*}{ January 18,2020} & \multirow[b]{3}{*}{$\begin{array}{l}\text { Adelphi } \\
\text { University }\end{array}$} & Tournament Champion & $16099 \mathrm{~A}$ \\
\hline & & Tournament Champion & 16099B \\
\hline & & Robot Skills Champion & $16099 \mathrm{~A}$ \\
\hline \multirow{6}{*}{ February 1, 2020} & \multirow{6}{*}{$\begin{array}{l}\text { Freeport High } \\
\text { School }\end{array}$} & Tournament Champion & $16099 \mathrm{~A}$ \\
\hline & & Tournament Champion & 16099B \\
\hline & & Tournament Finalist & $16699 \mathrm{Z}$ \\
\hline & & Robot Skills Champion & $16099 \mathrm{~A}$ \\
\hline & & Amaze Award & $16699 \mathrm{Y}$ \\
\hline & & Think Award & $16099 \mathrm{~A}$ \\
\hline \multirow{6}{*}{ February 29,2020} & \multirow{6}{*}{$\begin{array}{c}\text { Vaughn } \\
\text { College of } \\
\text { Aeronautics } \\
\text { and } \\
\text { Technology }\end{array}$} & $\begin{array}{c}\text { Middle School } \\
\text { Excellence Award }\end{array}$ & $16699 \mathrm{Z}$ \\
\hline & & Tournament Finalist & $16099 \mathrm{~A}$ \\
\hline & & Tournament Finalist & $16099 \mathrm{~B}$ \\
\hline & & $\begin{array}{c}\text { Tournament Semi- } \\
\text { finalist }\end{array}$ & $16699 \mathrm{Y}$ \\
\hline & & Robot Skills Champion & $16099 \mathrm{~A}$ \\
\hline & & Amaze Award & $16099 \mathrm{C}$ \\
\hline \multirow{2}{*}{ March 7, 2020} & \multirow[b]{2}{*}{$\begin{array}{l}\text { The Harvey } \\
\text { School } \\
\text { State } \\
\text { Championship }\end{array}$} & Tournament Champion & $16099 \mathrm{~A}$ \\
\hline & & Tournament Champion & 16099B \\
\hline
\end{tabular}

\section{PROGRAM OUTCOMES}

The overall purpose of the program is not only to improve the competition outcomes of first year VEX Competition but increase the different skills and assets that students can use in the future as well. Furthermore, the ultimate objective of the program was to cultivate an interest and passion for STEM related fields in the students of Overclock. In the beginning of the program, students presented very little knowledge in robotics and it was evident that public speaking and presentation skills were very low. Many students struggled in maintaining an audible volume when speaking and would stutter in presentations in front of strangers. As the training program ended, it was evident that students were speaking confidently at an audible level while maintaining a professional posture. There was also a decrease in stuttering and mumbling during presentation and understood the importance of an organized presentation. Furthermore, students were able to confidently create solutions to problems encountered and were able to identify possible robot designs for previous VEX robotics competition challenges.

In the beginning of the program, students were given a survey about their past experiences in VEX, STEM knowledge, and professional skills. At the end of the program the students were asked to complete the same survey after completing the program. Each question required a score between one and ten with one being strongly disagree and ten being strongly agree. The survey questions were as follows:

1. I know how to confidently build all the subsystems of a VEX Competition robot.

2. I am knowledgeable in the robotics components and sensors necessary to build a robot.

3. I can confidently create a working autonomous and driver control in a competition.

4. I can confidently create a VEX competition engineering notebook that meets all competition criteria.

5. I can confidently compete in the VEX Robotics competition.

6. I can confidently create a technical presentation and perform a proper presentation.

7. I believe I have the interview skills necessary to succeed in the future.

8. I believe I am ready to pursue a career in a STEM related field.

In the start of the program, more than $90 \%$ of the students provided a score of 3 or below for questions one through five. For questions six through seven, $80 \%$ of the students provided a score of 5 or below. However, we saw a major change in the survey results at the end of the program. More than $90 \%$ of the students provided a score of 8 or more for the first five questions. In questions six through eight students provided a score of 7 or more. Several students however provided a neutral score as they believed that certain topics in the program were difficult to follow. 


\section{CONCLUSION}

The overall purpose of the program is not only to improve the competition outcomes of first year VEX robotics students in STEM, but provide them with the confidence, skills, and knowledge needed to succeed in a STEM related field. Overall the program proved to be successful in providing a wellrounded STEM program that truly engages students in STEM, particularly in the field of engineering and design. Like any other program however, many improvements can be made to better the program. One improvement is to increase the meeting times per week allowing students to have more time to understand the class material. Furthermore, more topics can be covered in the summer curriculum as the program is set to end in the middle of August. This will allow the students more time for hands-on work and mentorship to strengthen their understanding.

Through the program however, it was seen that students have shown drastic improvements during the competition season and all the team members have shown drastic improvement during competition season. Students through the program were able to aid other members of their teams. An example of this was that programmers were able to aid the builders in the mechanical design and build, and mechanical members were able to aid the programmers in the autonomous development. Furthermore, teams showed excellent understanding in control theory and PID tuning.

\section{ACKNOWLEDGMENT}

The authors would like to thank Vaughn College of Aeronautics and Technology and the Department Chair of Engineering and technology, Dr. Hossein Rahemi, for their enthusiastic and continues support. Furthermore, we would like to acknowledge KG Computech Inc. and KG Tsang for his continuous support and participation in the STEM program development.

\section{REFERENCES}

[1] “2019-20 VEX Robotics Competition Game.” VEX Robotics, VEX RECF, 4 Feb. 2020, www.vexrobotics.com/vexedr/competition/vrccurrent-game

[2] J.R. Zubrriain, N. Kumia, Shouling He (2015), "Developing Courseware for Robotics in PreEngineering Education for High School Students", Prc. Of the 2015 American Society for Engineering Education Annual Conference, Seattle WA, June 14-17.

[3] N.S. Salzmann, G.D. Ricco, and M.W. Ohland, (2014) "Pre-college engineering participation among first-year engineering students", Prc. Of the 2014 American Society for Engineering Education Annual Conference, Indianapolis, IN, June 15-18.

[4] "VCS Command Reference." VCS API Reference, VEX Robotics , help.vexcodingstudio.com/index.html\#pro/namespacevex/classvex_1_1m otor/velocity.

[5] Caro, Irene Alvarez. "VEX Robotics: STEM Program and Robotics Competition Expansion into Europe." SpringerLink, Springer, Berlin, Heidelberg, 15 June 2011, link.springer.com/chapter/10.1007/978-3-64221975-7_2. 